DOI: doi.org/10.21009/JRMSI.009.1.02

\title{
ANALISIS KINERJA PEGAWAI PT TIRTA INVESTAMA
}

\author{
Mutia Windi Astuti \\ Jurusan Manajemen, Fakultas Ekonomi Universitas \\ Bhayangkara Jakarta Raya \\ Eri Bukhari \\ Jurusan Manajemen, Fakultas Ekonomi Universitas \\ Bhayangkara Jakarta Raya \\ Email: eri_bukhari@yahoo.com
}

\begin{abstract}
ABSTRAK
Tujuan dari penelitian ini adalah untuk mengetahui pengaruh penempatan kerja dan pelatihan terhadap kinerja karyawan pada PT Tirta Investama. Metode yang digunakan dalam penelitian ini adalah deskriptif kuantitatif dengan teknik pengumpulan data berupa penyebaran kuesioner pada sejumlah responden yang merupakan karyawan PT Tirta Investama. Jumlah responden dalam penelitian ini adalah 92 orang. Hasil penelitian yang dilakukan menunjukkan bahwa penempatan kerja secara parsial tidak mempengaruhi kinerja karyawan pada PT Tirta Investama.Berbanding terbalik dengan hasil uji variabel pelatihan yang menunjukkan bahwa pelatihan memiliki pengaruh positif terhadap kinerja karyawan pada PT Tirta Investama. Sedangkan penempatan kerja dan pelatihan secara bersamaan berpengaruh signifikan terhadap kinerja karyawan di PT Tirta Investama.
\end{abstract}

Kata kunci: Penempatan Kerja, Pelatihan, Kinerja Karyawan 


\section{PENDAHULUAN}

Sumber daya manusia merupakan modal utama peningkatan daya saing pada era globalisasi. Setiap fenomena sosial yang terjadi pada saat ini dan masa mendatang ditentukan oleh pengelolaan sumber daya manusia. Pengelolaan sumber daya manusia yang strategis memandang bahwa karyawan adalah salah satu bagian dari faktor produksi, sehingga perlu dimanfaatkan secara optimal dan produktif namun tetap bijaksana, meskipun suatu perusahaan memiliki peralatan canggih sekalipun, tujuan dari perusahaan tidak akan tercapai tanpa adanya peran aktif dari salah satu faktor produksi berupa karyawan.

Keberhasilan bagi perusahaan berawal dari adanya pengetahuan, keterampilan serta kerjasama antar karyawan di suatu perusahaan. Peningkatan mutu hasil pekerjaan bukan hanya terkait masalah produk (barang atau jasa) yang dihasilkan serta dipasarkan saja, melainkan terkait pula segala jenis kegiatan organisasi yang ada, terutama bagaimana sebuah tim kerja saling bekerjasama untuk menghasilkan sinergi positif melalui usaha dan komunikasi yang terkoordinasi. Untuk mencapai tujuan dari perusahaan, maka perlunya menempatkan karyawan pada posisi yang tepat serta memiliki pengetahuan mengenai pelaksanaan tugas maupun pengetahuan umum (yang berkaitan dengan pelaksanaan tugas).

Karyawan dengan pengetahuan yang minim (seperti karyawan baru) akan mengalami kendala diawal bekerja sehingga pekerjaannya pun akan tersendat-sendat. Hal ini dapat memicu terjadinya pemborosan terhadap faktor produksi. Dengan adanya pemboroson yang terjadi, dapat dipastikan bahwa biaya pencapaian tujuan pun akan meningkat. Atas dasar inilah, suatu perusahaan perlu melakukan pembinaan serta pengembangan terhadap karyawan agar dapat menekan biaya pemborosan tersebut.

Salah satu kunci untuk mencapai kesuksesan dalam pencapaian tujuan adalah dengan adanya keterampilan kerja. bagi karyawan baru, atau yang menghadapi pekerjaan baru, diperlukan tambahan keterampilan untuk dapat melakasanakan tugas dengan baik selain pengetahuan dasar yang cukup memadai, namun keterampilan dan pengetahuan saja tidaklah cukup, sikap (attitude) karyawan juga merupakan salah satu kunci dalam mencapai keberhasilan, sehingga, pelatihan terhadap karyawan dirasa penting untuk dilakukan.

Dalam hasil wawancara terungkap bagaimana cara serta kriteria yang ditetapkan oleh PT Tirta Investama dalam menempatkan para karyawan di perusahaan tersebut. PT Tirta Investama atau yang dikenal dengan Aqua merupakan sebuah perusahaan pelopor air mineral dalam kemasan di Indonesia. Mengingat pentingnya menempatkan seorang pegawai yang tepat untuk sebuah posisi atau jabatan tertentu, maka perusahaan pun harus menentukan kriteria serta 
penilaian khusus agar tidak salah dalam mempercayakan seseorang dalam bekerja. Selain itu karyawan PT Tirta Investama dalam wawancara saat itu mengatakan bahwa masih adanya penempatan kerja bagi karyawan yang tidak sesuai dengan latar belakang pendidikan sehingga membuat karyawan merasa kesulitan mengerjakan suatu pekerjaan dan harus lebih banyak belajar dan bertanya dengan karyawan lain agar dapat menyelesaikan pekerjaan tersebut. Kondisi ini menimbulkan timbul beberapa fenomena seperti adanya karyawan yang bekerja tanpa semangat, rasa gelisah, kurang nyaman atau bahkan timbul rasa kurang percaya diri dalam menyelesaikan pekerjaan yang menjadi tanggung jawab karyawan tersebut.

Pada kesempatan berbeda dilakukan wawancara dengan narasumber yang berbeda pula, mereka mengatakan bahwa keterampilan yang mereka miliki serta pengetahuan akan pekerjaan yang mereka emban ketika diawal bekerja tidaklah memadai, sehingga lagi-lagi kunci utama bagi karyawan untuk menghadapi situasi tersebut adalah dengan banyak bertanya kepada karyawan lain yang lebih mengerti dan memahami kualifikasi pekerjaan tersebut. Kemudian pegawai lainnya menambahkan bahwa kurangnya pengalaman kerja yang dimiliki pegawai dalam melaksanakan pekerjaan yang dibebankan kepada dirinya. Selain itu, pegawai yang bersangkutan mengatakan bahwa masih adanya penempatan kerja yang dilakukan oleh perusahaan dengan mengabaikan pengetahuan, kemampuan serta keterampilan yang dimiliki oleh karyawan.

Berdasarkan hal tersebut, timbul sebuah pertanyaan bagi penulis, apakah yang menjadi pertimbangan utama dari perusahaan tersebut dalam menempatkan karyawannya jika sebenarnya mereka tidak memiliki keterampilan serta pengetahuan akan pekerjaan yang diberikan kepada mereka? Selain itu juga, apakah sebenarnya dengan adanya pelatihan bagi karyawan dirasa tepat untuk meningkatkan kinerja karyawan? Dengan melihat permasalahan tersebut diatas, menarik minat penulis untuk melakukan penelitian tentang penempatan kerja dan pelatihan karyawan PT Tirta Investama dengan judul "Analisis Penempatan Kerja dan Pelatihan Terhadap Kinerja Pegawai di PT Tirta Investama".

Berdasarkan latar belakang tersebut, maka penulis mengidentifikasi rumusan masalah pada penelitian ini adalah:

1. Apakah proses penempatan kerja berpengaruh secara signifikan terhadap kinerja karyawan PT Tirta Investama?

2. Apakah proses pelatihan berpengaruh secara signifikan terhadap kinerja karyawan PT Tirta Investama? 
3. Apakah proses penempatan kerja dan pelatihan secara simultan berpengaruh terhadap kinerja karyawan PT Tirta Investama?

Seteleh meruuskan masalah penulis menetapkan tujuan yang ingin dicapai dari hasil penelitian ini sebagai berikut:

1. Untuk mengetahui bagaimana pengaruh dari penempatan kerja terhadap kinerja karyawan di PT Tirta Investama.

2. Untuk mengetahui bagaimana pengaruh dari pelatihan terhadap kinerja karyawan di PT Tirta Investama.

3. Untuk mengetahui secara simultan bagaimana penempatan kerja dan pelatihan terhadap kinerja karyawan di PT Tirta Investama.

Dalam penelitian ini banyak masalah yang dapat diangkat dalam penelitian ini, namun agar masalahnya terperinci dan pemecahan masalah dapat terarah dan berhasil maka penulis membatasi penelitian ini hanya pada masalah pengaruh penempatan kerja dan pelatihan terhadap kinerja karyawan di PT Tirta Investama.

\section{TELAAH PUSTAKA}

\section{Kinerja}

Menurut H Malayu (2007) kinerja pegawai merupakan suatu hasil kerja yang dicapai seseorang dalam melaksanakan tugas-tugas yang diberikan kepadanya berdasarkan atas kecakapan pengalaman dan kesungguhan serta waktu. Kemudian Arif Yusuf Hambali (2016) menambahkan bahwa kinerja merupakan hasil pekerjaan yang mempunyai hubungan kuat dengan tujuan strategi organisasi, keputusan konsumen, dan memberikan kontribusi pada ekonomi. Sedangkan Wirawan (2012) mengatakan kinerja adalah keluaran yang dihasilkan oleh fungsi-fungsi atau indikator-indikator suatu pekerjaan atau suatu profesi dalam waktu tertentu. Definisi kinerja juga ditambahkan oleh Bangun (2012) bahwa kinerja adalah hasil pekerjaan yang dicapai seseorang berdasarkan per syaratan-persyaratan pekerjaan.

\section{Indikator Kinerja}

Menurut Robbins (2006) beberapa indikator yang dapat digunakan untuk mengukur kinerja secara individu, yaitu sebagai berikut:

a. Kualitas kerja. Ini diukur dari persepsi karyawan terhadap kualitas pekerjaan yang dihasilkan serta kesempurnaan tugas terhadap keterampilan dan kemampuan karyawan. 
b. Kuantitas. Merupakan jumlah yang dihasilkan dinyatakan dalam istilah seperti jumlah unit, jumlah siklus aktivitas yang diselesaikan.

c. Ketepatan waktu. Merupakan tingkat aktivitas diselesaikan pada awal waktu yang dinyatakan, dilihat dari sudut koordinasi dengan hasil output serta memaksimalkan waktu yang tersedia untuk aktivitas lain.

d. Efektivitas. Merupakan tingkat penggunaan sumber daya organisasi (tenaga, uang, teknologi, bahan baku) dimaksimalkan dengan maksud menaikkan hasil dari setiap unit dalam penggunaan sumber daya.

e. Kemandirian. Merupakan tingkat seorang karyawan yang nantinya akan dapat menjalankan fungsi kerjanya.

f. Komitmen kerja. merupakan suatu tingkat dimana karyawan mempunyai komitmen kerja dengan instansi dan tanggung jawab karyawan terhadap kantor.

\section{Penempatan Kerja}

Menurut Hariandjo (2006) penempatan kerja merupakan proses penugasan/pengisisan jabatan atau penugasan kembali pada tugas/jabatan baru atau jabatan yang berbeda. Pendapat yang hampir serupa juga disebutkan oleh Malayu S.P. Hasibuan (2008), mengemukakan bahwa "penempatan karyawan adalah tindak lanjut dari seleksi, yaitu menempatkan calon karyawan yang diterima pada jabatan/pekerjaan yang dibutuhkannya dan sekaligus mendelegasikan authority kepada orang tersebut". Sedangkan menurut Veithzal Rivai dan Ella Jauvani Sagala (2009) "Penempatan adalah penugasan kembali seorang karyawan kepada pekerjaan barunya".

\section{Indikator Penempatan Kerja}

Dikutip dari Suwatno (2003), dalam melakukan penempatan karyawan hendaknya mempertimbangkan hal-hal sebagai berikut:

a. Pendidikan

Pendidikan merupakan salah satu penentu dari penempatan kerja karyawan.Dalam hal ini pendidikan biasanya digunakan sebagai bagian untuk menentukan jenjang karir serta posisi atau jabatan seseorang. Pendidikan minimum disyaratkan dalam melamar pekerjaan seperti :pendidikan yang disyaratkan oleh perusahaan dan pendidikan alternative

b. Pengetahuan Kerja 
Pengetahuan kerja yang dimaksud adalah pengetahuan pegawai tentang pekerjaan yang dilakukan baik sebelum bekerja maupun pengetahuan yang didapat setelah bekerja.

c. Keterampilan Kerja

Didalam praktek kerja, keterampilan kerja berarti kecakapan serta keahlian yang dimiliki oleh karyawan. Keterampilan kerja ini dapat berupa :

- Keterampilan mental seperti halnya menganalisa data-data serta menentukan sikap dalam pengambilan keputusan.

- Keterampilan fisik seperti kemampuan diri dalam melakukan sesuatu dalam hal ini seorang teknisi atau mekanik.

- Keterampilan sosial seperti kemampuan dalam mempengaruhi orang lain, menawarkan produk baik itu barang maupun jasa.

d. Pengalaman Kerja

Pengalaman kerja dapat dijadikan sebagai pertimbangan tertentu oleh perusahaan.pengalaman kerja yang dimaksud adalah pengalaman serta seberapa lama waktu yang telah dilewati untuk melakukan pekerjaan tertentu.

\section{Syarat Penempatan Kerja}

Menurut Rosidah (2003) ada beberapa persyaratan penting yang harus dipenuhi dalam rangka penempatan pegawai, adapun persyaratan yang harus dipenuhi tersebut adalah sebagai berikut:

a. Informasi analisis jabatan yang memberikan deskripsi jabatan, spesialisasi jabatan dan standar prestasi yang seharusnya ada dalam setiap jabatan tersebut.

b. Rencana-rencana Sumber Daya Manusia yang akan memberikan manajer tentang tersedia tidaknya lowongan pegawai suatu instansi.

c. Keberhasilan fungsi rekrutmen yang akan menjamin manajer bahwa tersedia sekelompok orang yang akan dipilih.

\section{Pelatihan}

Menurut Edy Sutrisno (2011) pelatihan pada dasarnya merupakan sebuah proses untuk meningkatkan kompetensi karyawan. Sedangkan Mangkuprawira (2007) mengatakan bahwa pelatihan adalah merupakan sebuah proses mengajarkan pengetahuan dan keahlian tertentu, serta sikap agar karyawan semakin terampil dan mampu melaksanakan tanggung jawabnya dengan semakin baik, sesuai dengan standar. 


\section{Faktor-faktor yang Mempengaruhi Pelatihan}

Adapun faktor-faktor yang mempengaruhi pelatihan menurut Marwansyah (2014) sebagai berikut:

a. Dukungan manajemen puncak. Program pelatihan harus mendapatkan dukungan penuh dari menajemen puncak dalam sebuah organisasi. Dukungan ini harus bersifat konkret dan perlu dikomunikasikan kepada seluruh bagian organisasi. Selanjutnya dukungan ini harus diwujudkan dalam bentuk sumber daya yang memadai untuk melaksanakan pelatihan dan pengembangan sumber daya manusia.

b. Komitmen para spesialis dan generalis dalam pengelolaan SDM. Dibutuhkan komitmen yang kuat dan keterlibatan para manajer generalis dalam pengelolaan sumber daya manusia, dan terutama para manajer spesialis pelatihan dan pengembangan SDM.

c. Perkembangan teknologi. Kemajuan teknologi tidak saja memberikan dampak pada identifikasi kebutuhan pelatihan dan pengembangan tetapi juga terhadap pemilihan metode pelatihan dan pengembangan.

d. Kompleksitas organisasi. Seorang pekerja yang sukses harus secara berkesinambungan meningkatkan atau memperbarui kompetensi mereka dan membangun sikap yang memungkinkan mereka untuk tidak hanya beradaptasi dengan perubahan tetapi juga menerima dan bahkan mencari perubahan.

e. Gaya belajar. Keberhasilan program pengembangan dan pelatihan sumberdaya manusia dipengaruhi oleh gaya belajar. Ketika seseorang dapat dikatakan telah belajar, bukan berarti menunjuk kepada perubahan perilaku yang bersifat sementara atau temporer. Seseorang disebut telah belajar jika pada dirinya terjadi perubahan perilaku yang bersifat menetap atau permanen.

f. Kinerja fungsi-fungsi manajemen SDM lainnya. Kinerja fungsi-fungsi manajemen SDM yakni, rekrutmen dan seleksi, pelatihan dan pengembangan, kompensasi, manajemen kinerja, perencanaan dan pengembangan karir, hubungan karyawan, manajemen PHK, dan administrasi personalia, serta sistem informasi SDM.

\section{Kerangka Pemikiran}

Berdasarkan latar belakang, pembahasan masalah, tinjauan literature dan penelitian

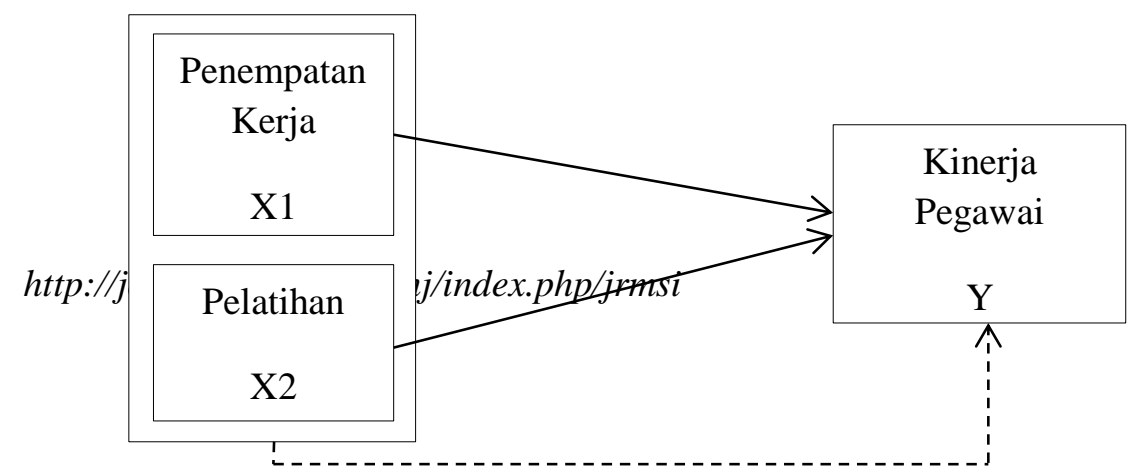


terdahulu maka kerangka penelitian ini adalah sebagai berikut

\section{Gambar 1. Kerangka Pemikiran}

\section{Hipotesis}

Berdasarkan pernyataan penelitian, tujuan penelitian, tinjauan pustaka dan kerangka pemikiran penelitian, maka dapat dirumuskan hipotesis penelitian berikut ini :

- Ha : Terdapat pengaruh positif dan signifikan antara variable penempatan kerja terhadap kinerja pegawai di PT Tirta Investama.

- Ho : Tidak terdapat pengaruh positif dan signifikan antara variable penempatan kerja terhadap kinerja pegawai di PT Tirta Investama.

- Ha : Terdapat pengaruh positif dan signifikan antara variable pelatihan kerja terhadap kinerja pegawai di PT Tirta Investama.

- Ho : Tidak terdapat pengaruh positif dan signifikan antara variable pelatihan terhadap kinerja pegawai di PT Tirta Investama.

- Ha : Secara bersama-sama terdapat pengaruh positif antara variable penempatan kerja dan pelatihan terhadap kinerja pegawai di PT Tirta Investama.

- Ho : Secara bersama-sama tidak terdapat pengaruh positif antara variable penempatan kerja dan pelatihan terhadap kinerja pegawai di PT. Tirta Investama.

\section{METODOLOGI PENELITIAN}

Penelitian ini menggunakan pendekatan deskriptif kuantitatif dengan desain cross sectional time sequence yaitu peneliti mengumpulkan data dengan menetapkan terlebih dulu konsep sebagai variabel-variabel yang berhubungan yang berasal dari teori yang sudah ada kemudian mencari data dengan menggunakan kuesioner untuk pengukuran variabel-variabel yakni penempatan kerja dan pelatihan di PT Tirta Investama sebagai variabel bebas dan kinerja pegawai sebagai variabel terikat. Tujuannya adalah untuk mengetahui keterkaitan pengaruh dan hubungan antara variabel penempatan kerja pegawai dan pelatihan terhadap kinerja pegawai, dengan menggunakan sistem komputerisasi program SPSS.

Menurut Sugiyono (2010) menjelaskan bahwa populasi adalah wilayah generalisasi yang terdiri atas obyek/subyek yang mempunyai kualitas dan karakteristik tertentu yang ditetapkan oleh peneliti untuk dipelajari dan kemudian ditarik kesimpulannya. Sedangkan sampel menurut 
menurut Sugiyono (2010) adalah bagian dari jumlah dan karakteristik yang dimiliki oleh populasi tersebut. Mengingat bahwa jumlah populasi cukup banyak, maka penentuan jumlah sampel dengan menggunakan Teori Slovin yang dapat ditentukan dengan rumus sebagai berikut:

$n=\frac{N}{1+\mathrm{N}(\mathrm{e})^{2}}$

Keterangan : $\quad \mathrm{n}=$ jumlah sampel

$\mathrm{N}=$ jumlah populasi

$\mathrm{e}=$ batas toleransi kesalahan $($ error tolerance $)$

Dengan menggunakan rumus Slovin tersebut maka didapatkan jumlah sampel sebanyak :

$n=\frac{N}{1+\mathrm{N}(\mathrm{e})^{2}}$

$n=\frac{119}{1+119(0,05)^{2}}$

$n=91,7$ atau dibulatkan menjadi 92

Dengan demikian maka dalam penelitian penulis menggunakan sampel sebanyak 92 orang.

\section{HASIL DAN PEMBAHASAN}

Nilai $r_{\text {tabel }}$ didapatkan dengan menggunakan rumus $d f=n-2$. Jika jumlah responden adalah 92 responden, maka $d f=92-2=90$. Maka jumlah $r_{\text {tabel }}$ dalam penelitian tersebut sebesar 0,207. Dengan jumlah tersebut, maka data yang dimiliki dapat dikatakan valid jikalebih

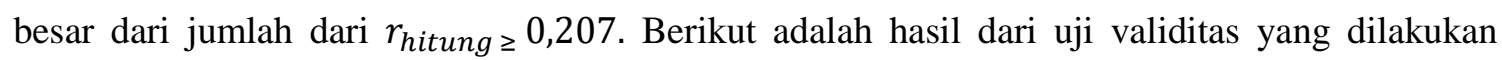
berdasarkan data kuesioner.

Tabel 1. Hasil Uji Validitas Penempatan Kerja

\begin{tabular}{ccccc}
\hline Variabel & Pernyataan & Nilai & Nilai $\boldsymbol{r}_{\text {tabel }}$ & Keterangan \\
& & $\boldsymbol{r}_{\boldsymbol{h i t u n g}}$ & & \\
\hline Penempatan Kerja & Pernyataan 1 & 0,469 & 0.207 & Valid \\
& Pernyataan 2 & 0,447 & 0.207 & Valid \\
& Pernyataan 3 & 0,455 & 0.207 & Valid \\
& Pernyataan 4 & 0,468 & 0.207 & Valid \\
\hline
\end{tabular}




\begin{tabular}{llll}
\hline Pernyataan 5 & 0,561 & 0.207 & Valid \\
Pernyataan 6 & 0,491 & 0.207 & Valid \\
Pernyataan 7 & 0,358 & 0.207 & Valid \\
Pernyataan 8 & 0,448 & 0.207 & Valid \\
Pernyataan 9 & 0,459 & 0.207 & Valid \\
Pernyataan 10 & 0,671 & 0.207 & Valid \\
\hline
\end{tabular}

Tabel 2. Hasil Uji Validitas Pelatihan

\begin{tabular}{lllll}
\hline Variabel & Pernyataan & Nilai & Nilai $\boldsymbol{r}_{\text {tabel }}$ & Keterangan \\
& & & \\
\hline Pelatihan & & & \\
\hline & Pernyataan 1 & 0,701 & 0.207 & Valid \\
Pernyataan 2 & 0,473 & 0.207 & Valid \\
Pernyataan 3 & 0,460 & 0.207 & Valid \\
Pernyataan 4 & 0,701 & 0.207 & Valid \\
Pernyataan 5 & 0,261 & 0.207 & Valid \\
Pernyataan 6 & 0,317 & 0.207 & Valid \\
Pernyataan 7 & 0,376 & 0.207 & Valid \\
Pernyataan 8 & 0,460 & 0.207 & Valid \\
Pernyataan 9 & 0,701 & 0.207 & Valid \\
Pernyataan 10 & 0,473 & 0.207 & Valid \\
\hline
\end{tabular}

Tabel 3. Hasil Uji Validitas Kinerja Pegawai

\begin{tabular}{ccccc}
\hline Variabel & Pernyataan & $\begin{array}{c}\text { Nilai } \\
\boldsymbol{r}_{\text {hitung }}\end{array}$ & Nilai $\boldsymbol{r}_{\text {tabel }}$ & Keterangan \\
\hline Kinerja Pegawai & Pernyataan 1 & 0,715 & 0.207 & Valid \\
& Pernyataan 2 & 0.498 & 0.207 & Valid \\
& Pernyataan 3 & 0,388 & 0.207 & Valid \\
& Pernyataan 4 & 0,715 & 0.207 & Valid \\
& Pernyataan 5 & 0,542 & 0.207 & Valid \\
& Pernyataan 6 & 0,365 & 0.207 & Valid \\
\hline
\end{tabular}




\begin{tabular}{cccc}
\hline Pernyataan 7 & 0,542 & 0.207 & Valid \\
Pernyataan 8 & 0,388 & 0.207 & Valid \\
Pernyataan 9 & 0,715 & 0.207 & Valid \\
Pernyataan 10 & 0,498 & 0.207 & Valid \\
\hline
\end{tabular}

Hasil dari uji reliabilitas dari masing-masing variabel menunjukkan hasil sebagai berikut :

Tabel 4. Uji Reliabilitas

\begin{tabular}{ccc}
\hline Variabel & Cronbach's Alpha (a) & Kesimpulan \\
\hline Penempatan Kerja & 0,627 & Reliabel \\
Pelatihan & 0,667 & Reliabel \\
Kinerja Pegawai & 0,729 & Reliabel \\
\hline
\end{tabular}

Berdasarkan hasil pengujian yang telah dilakukan, diketahui nilai dari Cronbach's Alpha sebesar 0,627 untuk penempatan kerja, 0,667 untuk pelatihan dan 0,729 untuk kinerja pegawai. Sesuai dengan persyaratan 0,60 adalah minimal dari nilai Chronbach's Alpha, maka dapat disimpulkan bahwa instrument dalam pengukuran variabel terikat dan bebasnya reliabel. 
Tabel 5. Hasil Uji t (Parsial)

Coefficients $^{\mathbf{a}}$

\begin{tabular}{|c|c|c|c|c|c|c|}
\hline \multirow{2}{*}{\multicolumn{2}{|c|}{ Model }} & \multicolumn{2}{|c|}{$\begin{array}{c}\text { Unstandardized } \\
\text { Coefficients }\end{array}$} & \multirow{2}{*}{$\begin{array}{c}\text { Standardized } \\
\text { Coefficients } \\
\text { Beta } \\
\end{array}$} & \multirow[b]{2}{*}{$\mathbf{T}$} & \multirow[b]{2}{*}{ Sig. } \\
\hline & & B & Std. Error & & & \\
\hline \multirow[t]{3}{*}{1} & (Constant) & 3.339 & 2.722 & & 1.227 & .223 \\
\hline & Penempatan & -.043 & .049 & -.044 & -.883 & .379 \\
\hline & Pelatihan & .965 & .053 & .896 & 18.197 & .000 \\
\hline
\end{tabular}

Dependent Variable: kinerja

a. Berdasarkan hasil perhitungan menggunakan SPSS 22 di dapatkan hasil bahwa nilai dari $t_{\text {hitung }}<t_{\text {tabel }}$ untuk variabel penempatan kerja, karena $-0,883<1,664$ dengan nilai Sig $>0,05$, sedangkan untuk variabel pelatihan nilai $t_{\text {hitung }}>t_{\text {tabel }}$, karena 18,197 > 1,664 dengan tingkat Sig < 0,05. Berdasarkan cara pengambilan keputusan dalam uji parsial dalam analisis regresi, maka ditarik kesimpulan bahwa :Variabel penempatan kerja secara parsial tidak berpengaruh signifikan terhadap kinerja pegawai.

b. Variabel pelatihan secara parsial berpengaruh secara signifikan terhadap kinerja pegawai. Berdasarkan hasil diatas menunjukkan bahwa variabel penempatan kerja tidak berpengaruh terhadap kinerja pegawai pada perusahaan tersebut, ini menunjukkan adanya gap teori penempatan kerja dengan kenyataan pelaksanaan yang ada pada PT Tirta Investama.

Adapun penjelasan dari hasil tersebut kemungkinan ini dipengaruhi oleh jumlah populasi/sampel dalam penelitian yang masih terlalu sedikit.Selain itu, adanya kemungkinan bahwa responden yang dijadikan sampel telah dipengaruhi oleh pelatihan, sehingga meskipun mereka berada pada posisi/jabatan yang tidak sesuai dengan latar belakang pendidikan, minat maupun keterampilannya, mereka beranggapan bahwa kesalahan dalam penempatan kerja tidak mempengaruhi kinerja mereka.Sehingga muncul persepsi bahwa penempatan kerja yang kurang tepat dapat diperbaiki dengan pemberian pelatihan yang efektif. 


\section{Tabel 6. Hasil Uji F}

\begin{tabular}{rlrrrrr}
\multicolumn{7}{c}{ ANOVA $^{\mathrm{a}}$} \\
\hline Model & & Sum of Squares & \multicolumn{1}{c}{ Df } & Mean Square & \multicolumn{1}{c}{ F } & \multicolumn{1}{c}{ Sig. } \\
\hline \multirow{2}{*}{1} & Regression & 970.240 & 2 & 485.120 & 168.505 & $.000^{\mathrm{b}}$ \\
& Residual & 256.227 & 89 & 2.879 & & \\
& Total & 1226.467 & 91 & & & \\
\hline
\end{tabular}

Dependent Variable: kinerja

Predictors: (Constant), pelatihan, penempatan

Berdasarkan hasil pada output SPSS 22 berupa tabel Anova seperti diatas, maka diketahui bahwa nilai $F_{\text {hitung }}>F_{\text {tabel }}$ dengan hasil 168,505 $>3,10$ dengan tingkat $\operatorname{Sig}<0,05$. Berdasarkan hasil tersebut, maka dapat diambil kesimpulan bahwa kedua variabel jika diuji secara bersama-sama akan berpengaruh signifikan terhadap kinerja pegawai.

\section{Tabel 7. Hasil Uji Regresi Linear Berganda}

Coefficients $^{\mathrm{a}}$

\begin{tabular}{|c|c|c|c|c|c|c|}
\hline \multirow{2}{*}{\multicolumn{2}{|c|}{ Model }} & \multicolumn{2}{|c|}{$\begin{array}{c}\text { Unstandardized } \\
\text { Coefficients }\end{array}$} & \multirow{2}{*}{$\begin{array}{c}\text { Standardized } \\
\text { Coefficients } \\
\text { Beta } \\
\end{array}$} & \multirow[b]{2}{*}{$\mathbf{T}$} & \multirow[b]{2}{*}{ Sig. } \\
\hline & & B & Std. Error & & & \\
\hline \multirow[t]{3}{*}{1} & (Constant) & 3.339 & 2.722 & & 1.227 & .223 \\
\hline & Penempatan & -.043 & .049 & -.044 & -.883 & .379 \\
\hline & Pelatihan & .965 & .053 & .896 & 18.197 & .000 \\
\hline
\end{tabular}

Dependent Variable: kinerja

Berdasarkan kriteria dalam pengambilan keputusan, maka hasil output SPSS 22 mengenai uji regresi linear berganda menunjukkan tingkat Sig penempatan kerja 0,379 $>0,05$, maka dapat dikatakan hipotesis nol ditolak yang artinya sesungguhnya variabel penempatan kerja tidak berpengaruh secara signifikan terhadap kinerja pegawai. Sedangkan untuk variabel pelatihan menunjukkan bahwa tingkat Sig < 0,05, sehingga Hipotesis alternatif diterima, yang artinya terdapat pengaruh signifikan pelatihan terhadap kinerja pegawai. Selain itu, dari tabel diatas dapat dilihat bahwa persamaan regresi linear bergandanya adalah $\mathrm{Y}=3,339-0,043 X_{1}+$ $0,965 X_{2}$.

Kemudian untuk pengujian terhadap variabel bebas secara bersama-sama, berikut hasilnya : 
Tabel 8. Uji F Anova

\begin{tabular}{llrrrrr}
\multicolumn{7}{c}{ ANOVA $^{\mathbf{a}}$} \\
\hline Model & & Sum of Squares & Df & Mean Square & \multicolumn{1}{c}{ F } & \multicolumn{1}{c}{ Sig. } \\
\hline \multirow{2}{*}{1} & Regression & 970.240 & 2 & 485.120 & 168.505 & $.000^{\mathrm{b}}$ \\
& Residual & 256.227 & 89 & 2.879 & & \\
& Total & 1226.467 & 91 & & & \\
\hline
\end{tabular}

Dependent Variable: kinerja

Predictors: (Constant), pelatihan, penempatan

Berdasarkan hasil output didapatkan nilai Sig $<0,05$ maka dapat diambil kesimpulan hipotesis alternatif diterima yang berarti bahwa penempatan kerja dan pelatihan berpengaruh secara bersama-sama terhadap kinerja pegawai.

\section{Tabel 9. Hasil Uji Koefisien Determinasi $\left(R^{2}\right)$}

Model Summary

\begin{tabular}{lrrrr} 
& \multicolumn{4}{c}{ Model Summary } \\
\hline Model & R & R Square & \multicolumn{2}{c}{ Adjusted R } \\
Square & Std. Error of the Estimate \\
\hline 1 & $.889^{\mathrm{a}}$ & .791 & .786 & 1.69675 \\
\hline
\end{tabular}

Predictors: (Constant), pelatihan, penempatan

Berdasarkan hasil koefisien determinasi diperoleh nilai Adjusted $R$ Square $=0,786$ atau setara dengan $78,6 \%$. Hal ini menunjukkan bahwa variasi dari kinerja karyawan dipengaruhi oleh penempatan kerja dan pelatihan sebesar 78,6\% dan sisanya $21,4 \%$ dipengaruhi faktor-faktor lain yang tidak termasuk dalam penelitian ini.

\section{KESIMPULAN}

Berdasarkan hasil pengujian dan analisa dalam penelitian yang telah dilakukan, penelitian ini memiliki tujuan untuk melihat apakah terdapat pengaruh pada penempatan kerja dan pelatihan yang diberikan kepada pegawai terhadap kinerja dari pegawai itu sendiri. Maka sesuai dengan hipotesis yang telah dirumuskan sebelumnya serta hasil yang ditunjukkan dalam penelitian ini, dapat ditarik kesimpulan sebagai berikut : 
1. Dari hasil perhitungan yang telah dilakukan dengan menggunakan SPSS 22, serta dengan menganalisis hasil yang telah didapatkan melalui perhitungan, maka didapatkan kesimpulan bahwa variabel penempatan kerja secara parsial tidak berpengaruh signifikan terhadap kinerja pegawai pada PT Tirta Investama.

2. Kemudian dari hasil perhitungan yang dilakukan untuk variabel bebas berupa pelatihan yang menggunakan SPSS 22 sebagai alat bantu hitung, serta dengan menganalisis hasil yang telah didapatkan melalui perhitungan, maka didapatkan kesimpulan bahwa variabel pelatihan secara parsial berpengaruh signifikan terhadap kinerja pegawai pada PT Tirta Investama

3. Selanjutnya, dari hasil perhitungan yang dilakukan, serta analisis dan pengujian terhadap variabel-variabel terkait, yaitu kinerja pegawai sebagai variable terikat, serta penempatan kerja dan pelatihan sebagai variabel bebasnya, maka didapatkan hasil bahwa penempatan kerja dan juga pelatihan sesungguhnya berpengaruh secara signifikan terhadap kinerja dari karyawan PT Tirta Investama.

\section{DAFTAR PUSTAKA}

Arif Yusuf Hamali, S. M. (2016). Pemahaman Manajemen Sumber Daya Manusia. Yogyakarta: CAPS.

Bangun, W. (2012). Manajemen Sumber Daya Manusia. Jakarta: Erlangga.

DR. Edy Sutrisno, M. (2011). Manajemen Sumber Daya Manusia. Rawamangun-Jakarta: KENCANA PRENADA MEDIA GROUP.

DRS. Danang Sunyoto, S. S. (2015). Manajemen Dan Pengembangan Sumber Daya Manusia. Yogyakarta: CAPS.

Drs. H. Malayu, S. H. (2007). Manajemen Sumber Daya Manusia. Jakarta: PT. Bumi Aksara.

Mangkunegara, A. P. (2009). Manajemen Sumber Daya Manusia. Bandung: PT. Remaja Rosdakarya.

Marwansyah. (2016). Manajemen Sumber Daya Manusia. Bandung: Alfabeta.

Rosidah, A. T. (2003). Manajemen Sumber Daya Manusia. Yogyakarta: Graha Ilmu.

Sugiyono, P. D. (2010). Metode Penelitian Bisnis. Bandung : Alfabeta,cv. 